\title{
MEDIASI INTEREST BASED DALAM PENYELESAIAN SENGKETA TANAH
}

\author{
Oleh: \\ Mulyani Zulaeha ${ }^{1}$ \\ Fakultas Hukum Universitas Lambung Mangkurat
}

\begin{abstract}
Abstrak
Meningkatnya perkara tanah di pengadilan memunculkan keinginan untuk mempercepat proses penyelesaian melalui pola penyelesaian di luar pengadilan. Berdasarkan Peraturan Menteri Agraria dan Tata Ruang/Kepala Badan Pertanahan Nasional Nomor 11 Tahun 2016 tentang Penyelesaian Kasus Pertanahan, sengketa tanah dapat diselesaikan melalui mediasi di luar pengadilan. Model mediasi yang cocok dalam penyelesaian sengketa tanah adalah mediasi berbasis kepentingan interest based, yaitu fokus mediasi diarahkan pada substansi kepentingan terbaik bagi kedua belah pihak berdasarkan pada aspek penyelesaian bersama dengan cara menyelesaikan akar persoalan, menghindari konflik berkepanjangan antara para pihak, serta adanya keinginan untuk mempunyai hubungan baik jangka panjang.
\end{abstract}

Kata kunci : Mediasi Berbasis Kepentingan, Penyelesaian Sengketa, Tanah

Abstract

The increasement of land disputes in the litigation process led to a desire to speed up the settlement process through a nonlitigation settlement. Based on the Minister of Agrarian and Spatial Layout/Head of National Land Agency Number 11 of 2016 concerning Land Dispute Settlement, land disputes can be resolved through mediation outside the courts. Mediation model that fits in a land dispute settlement is interest-based mediation, which the focus of mediation is directed at the substance of the best interests of both parties based on the aspects of the settlement along with how to solve the root of the problems, avoid prolonged conflict between the parties, as well as their desire for a long-term good relations.

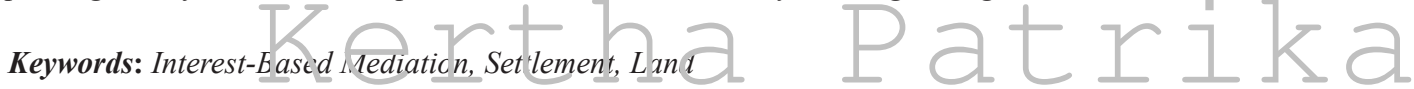

\section{Pendahuluan}

\section{I.1 Latar Belakang}

Sengketa merupakan bagian dari kehidupan manusia sebagai makhluk sosial. Interaksi antar manusia memungkinkan timbulnya masalah, jika para pihak dapat menyelesaikan masalahnya sendiri dengan baik, maka sengketa tidak akan terjadi. Sebaliknya jika para pihak tidak dapat mencapai kesepakatan mengenai solusi pemecahan masalahnya, maka akan timbul sengketa ${ }^{2}$. Pada prinsipnya manusia akan selalu mencari cara penyelesaian sengketa yang terbaik bagi kelanjutan kehidupan mereka, namun seiring perjalanan waktu permasalahan yang terjadi menjadi semakin kompleks dan rumit, maka penyelesaian sengketa pun mengalami perkembangan.

Penyelesaian sengketa perdata secara garis besar dapat dibagi dengan dua cara, yaitu penyelesaian sengketa secara litigasi (peradilan) dan bentuk penyelesaian sengketa secara non litigasi (diluar pengadilan). Setiap masyarakat memiliki cara untuk memperoleh kesepakatan dalam menentukan pilihan penyelesaian sengketa. Cara yang dipakai pada penyelesaian suatu sengketa tertentu akan memiliki konsekuensi, baik bagi para pihak yang bersengketa maupun

1 Mulyani Zulaeha adalah staff pengajar di Fakultas Hukum Universitas Lambung Mangkurat Jalan H. Hasan Basri Kayutangi. Banjarmasin

2 Rachmadi Usman. 2003. Pilihan Penyelesaian Sengketa Diluar Pengadilan, Bandung: Penerbit Citra Aditya Bakti, h. 
masyarakat dalam arti luas. Oleh karena terdapat konsekuensi dari pilihan penyelesaian sengketa tersebut, maka dalam memilih mekanisme yang paling tepat para pihak perlu memperhatikan bentuk persoalan dan apa yang diharapkan para pihak dalam penyelesaian sengketa serta biayabiaya yang dapat atau sedianya ditanggung oleh para pihak ${ }^{3}$.

Meningkatnya perkara di pengadilan dan banyaknya kritikan terhadap lembaga pengadilan memunculkan ide untuk lebih memberdayakan pola penyelesaian di luar pengadilan. Frank Sander dari Harvard Univercity pada tahun 1976 telah meramalkan solusi terkait hal tersebut, yaitu dengan mencegah terjadinya sengketa dan mengeksplor alternatif penyelesaian sengketa diluar pengadilan ${ }^{4}$. Penyelesaian sengketa di luar pengadilan merupakan bentuk respon kecenderungan peningkatan penumpukan perkara di pengadilan.

Terdapat beberapa model penyelesaian sengketa diluar pengadilan, seperti negosiasi, mediasi dan arbitrase. Seiring dengan peningkatan jumlah perkara yang masuk di pengadilan maka mediasi mendapat banyak perhatian untuk membantu memecahkan permasalahan penumpukan perkara di pengadilan. Mediasi dianggap sebagai bentuk penyelesaian sengketa yang dapat memenuhi keinginan para pihak, mempersingkat waktu dan biaya ${ }^{5}$. Mediasi merupakan suatu proses negosiasi yang dibantu oleh pihak ketiga ${ }^{6}$. Hal itu disebabkan para pihak yang tidak mampu menyelesaiakan sengketanya sendiri menggunakan jasa pihak ketiga yang bersikap netral untuk membantu mereka mencapai suatu kesepakatan. Kehadiran pihak ketiga (mediator) dalam mediasi tidak seperti pihak ketiga (hakim) dalam proses peradilan yang menerapkan hukum terhadap fakta-fakta yang ada untuk mencapai suatu hasil, dalam mediasi pihak ketiga akan mem-

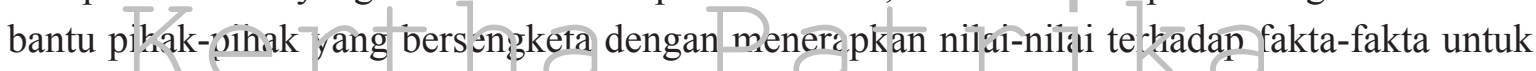
mencapai hasıl akhır. Nilai-nilai itu dapat meliputi hukum, rasa keadilan, kepercayaan, agama, etika, moral dan lain-lain.

Kasus pertanahan ${ }^{7}$ merupakan salah satu persoalan yang banyak diajukan ke pengadilan. Tanah merupakan bagian yang tidak terpisahkan dengan kehidupan manusia di muka bumi. Seiring dengan pertambahan jumlah penduduk, perkembangan pembangunan yang pesat, tentu berbanding lurus dengan kebutuhan akan tanah, baik untuk tempat tinggal, pembangunan, maupun kebutuhan lainnya yang menunjang kehidupan manusia. Hal ini tentu dapat memicu terjadinya masalah berkaitan dengan tanah. Masalah tanah yang muncul di kalangan masyarakat terus mengalami peningkatan dan makin kompleks. Terjadi ketidakseimbangan antara masalah yang timbul dengan pola penyelesaiannya yang dinilai lamban.

\footnotetext{
3 Gunawan Widjaja dan Ahmad Yani. 2000. Hukum Arbitrase, Jakarta: Penerbit Raja Grafindo Persada, h. 3

4 Naskah Akademik MARI. Tahun 2005 Tentang Pembaharuan Sistem Peradilan. h. xix

5 ibid.

6 Prosiding Mahkamah Agung RI. 2005. Mediasi dan Court Annexed Mediation. Jakarta: Penerbit Mahkamah Agung RI dan Pusat Pengkajian Hukum. h. 33

7 Kasus Pertanahan adalah Sengketa, Konflik, atau Perkara pertanahan untuk mendapatkan penanganan penyelesaian sesuai dengan ketentuan peraturan perundang-undangan dan/atau kebijakan pertanahan. Sengketa Tanah adalah perselisihan pertanahan antara orang perseorangan, badan hukum, atau lembaga yang tidak berdampak luas. Konflik Tanah adalah perselisihan pertanahan antara orang perseorangan, kelompok, golongan, organisasi, badan hukum, atau lembaga yang mempunyai kecenderungan atau sudah berdampak luas. Sedangkan Perkara Tanah adalah perselisihan pertanahan yang penanganan dan penyelesaiannya melalui lembaga peradilan. Lihat Pasal 1 angka 1, 2, 3 dan 4 Peraturan Menteri Agraria Dan Tata Ruang/Kepala Badan Pertanahan Nasional Nomor 11 Tahun 2016 tentang Penyelesaian Kasus Pertanahan.
} 
Sengketa tanah adalah perselisihan pertanahan antara orang perseorangan, badan hukum atau lembaga yang tidak berdampak luas secara sosio-politis. Penekanan yang tidak berdampak luas inilah yang membedakan definisi sengketa tanah dengan definisi konflik pertanahan. Sengketa tanah dapat berupa sengketa administratif, sengketa perdata, sengketa pidana terkait dengan pemilikan, transaksi, pendaftaran, penjaminan, pemanfaatan, penguasaan dan sengketa hak ulayat. Konflik pertanahan merupakan perselisihan pertanahan antara orang perseorangan, kelompok, golongan, organisasi, badan hukum atau lembaga yang mempunyai kecenderungan atau sudah berdampak luas secara sosio-politis. Perkara pertanahan adalah perselisihan pertanahan yang penyelesaiannya dilaksanakan oleh lembaga peradilan atau putusan lembaga peradilan yang masih dimintakan penanganan perselisihannya di Badan Pertanahan Nasional Republik Indonesia (BPN RI).

Tipologi kasus pertanahan merupakan jenis sengketa, konflik dan atau perkara pertanahan yang disampaikan atau diadukan dan ditangani oleh Badan Pertanahan Nasional, secara garis besar dikelompokkan menjadi:

1. Penguasaan tanah tanpa hak, yaitu perbedaan persepsi, nilai atau pendapat, kepentingan mengenai status penguasaan di atas tanah tertentu yang tidak atau belum dilekati hak (tanah negara), maupun yang telah dilekati hak oleh pihak tertentu.

2. Sengketa batas, yaitu perbedaan pendapat, nilai kepentingan mengenai letak, batas dan luas bidang tanah yang diakui satu pihak yang telah ditetapkan oleh Badan Pertanahan Nasional Republik Indonesia maupun yang masih dalam proses penetapan batas.

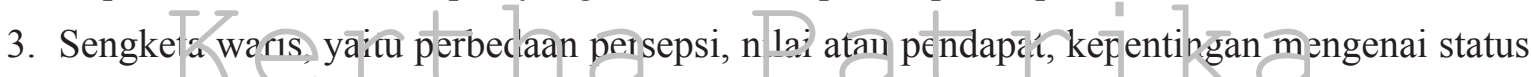
penguasaan di atas tanah tertentu yang berasal darı warısan.

4. Jual berkali-kali, yaitu perbedaan persepsi, nilai atau pendapat, kepentingan mengenai status penguasaan di atas tanah tertentu yang diperoleh dari jual beli kepada lebih dari 1 orang.

5. Sertipikat ganda, yaitu perbedaan persepsi, nilai atau pendapat, kepentingan mengenai suatu bidang tanah tertentu yang memiliki sertipikat hak atas tanah lebih dari 1.

6. Sertipikat pengganti, yaitu perbedaan persepsi, nilai atau pendapat, kepentingan mengenai suatu bidangtanah tertentu yang telah diterbitkan sertipikat hak atas tanah pengganti.

7. Akta Jual Beli Palsu, yaitu perbedaan persepsi, nilai atau pendapat, kepentingan mengenai suatu bidang tanah tertentu karena adanya Akta Jual Beli palsu.

8. Kekeliruan penunjukan batas, yaitu perbedaan pendapat, nilai kepentingan mengenai letak, batas dan luas bidang tanah yang diakui satu pihak yang teiah ditetapkan oleh Badan Pertanahan Nasional Republik Indonesia berdasarkan penunjukan batas yang salah.

9. Tumpang tindih, yaitu perbedaan pendapat, nilai kepentingan mengenai letak, batas dan luas bidang tanah yang diakui satu pihak tertentu karena terdapatnya tumpang tindih batas kepemilikan tanahnya.

10.Putusan Pengadilan, yaitu perbedaan persepsi, nilai atau pendapat, kepentingan mengenai putusan badan peradilan yang berkaitan dengan subyek atau obyek hak atas tanah atau mengenai prosedur penerbitan hak atas tanah tertentu.

8 Anonim, http://www.bpn.go.id/Program/Penanganan-Kasus-Pertanahan, diakses tanggal 29 oktober 2016. 
Menurut Mudjiono9, ada beberapa faktor yang menyebabkan timbulnya sengketa tanah. Pertama, peraturan yang belum lengkap, kedua, ketidaksesuaian peraturan, ketiga, pejabat pertanahan yang kurang tanggap terhadap kebutuhan dan jumlah tanah yang tersedia, keempat, data yang kurang akurat dan kurang lengkap, kelima, data tanah yang keliru, keenam, keterbatasan sumber dayan manusia yang bertugas menyelesaikan sengketa tanah, ketujuh, transaksi tanah yang keliru, dan kedelapan, adanya penyelesaian dari instansi lain, sehingga terjadi tumpang tindih kewenangan.

Pada hakikatnya sengketa tanah merupakan benturan kepentingan (conflick of interest) di bidang pertanahan antara siapa dengan siapa. Sengketa tanah secara umum dapat berupa masalah yang menyangkut prioritas untuk dapat ditetapkan sebagai pemegang hak atas tanah yang berstatus hak atau atas tanah yang belum ada haknya,bantahan terhadap suatu alas hak/ bukti perolehan yang digunakan sebagai dasar pemberian hak, kekeliruan/kesalahan pemberian hak yang disebabkan penerapan peraturan yang tidak benar ${ }^{10}$.

Sengketa tanah pada dasarnya memiliki beberapa sifat, yaitu pertama, sengketa tanah bersifat administrasi, kedua, sengketa tanah bersifat perdata, dan ketiga, sengketa tanah yang bersifat pidana. Sengketa tanah yang bersifat perdata, merupakan sengketa yang melibatkan antara individu atau lebih satu individu dengan individu lain. Karakteristik sengketa tanah yang bersifat perdata berbeda dengan sengketa perdata pada umumnya, dimana masing-masing individu saling menuntut hak dan kewajibannya. Dalam sengketa tanah maka para pihak yang bersengketa tidak bisa lepas dari peran pemerintah dalam hal ini Badan Pertanahan Nasional. Sengketa tanah yang dapar diselesaikan melilui mediasi di iuar pengarlilan adalah" sengketa tanah dalam ruang lingkup perdata yang berada di luarkewenargan Keinenterian.

Dalam kerangka mempercepat proses penyelesaian kasus pertanahan maka dikeluarkanlah Peraturan Menteri Agraria Dan Tata Ruang/Kepala Badan Pertanahan Nasional Nomor 11 Tahun 2016 tentang Penyelesaian Kasus Pertanahan, yang dimaksudkan untuk mengetahui riwayat dan akar permasalahan baik sengketa, konflik maupun perkara pertanahan. Penyelesaian kasus pertanahan ditujukan agar dapat memberikan kepastian hukum dan keadilan mengenai penguasaan, pemilikan, penggunaan dan pemanfaatan tanah.

Penyelesaian sengketa dan konflik tanah dapat dilakukan oleh kantor pertanahan, kantor Wilayah BPN atau Dirjen, terhadap pengaduan atau pemberitaan pada surat kabar terkait sengketa atau konflik. Penyelesaian sengketa dan konflik menurut Peraturan Menteri Agraria Dan Tata Ruang/Kepala Badan Pertanahan Nasional Nomor 11 Tahun 2016 dbedakan menjadi penyelesaian sengketa dan konflik yang merupakan kewenangan kementerian dan yang bukan kewenangan kementerian.

Penyelesaian sengketa atau konflik yang bukan kewenangan kementerian, menurut Pasal 12 ayat (5) juncto Pasal 37 Peraturan Menteri Agraria Dan Tata Ruang/Kepala Badan Pertanahan Nasional Nomor 11 Tahun 2016 dapat dilakukan melalui mediasi.

9 Mudjiono, Alternatif Penyelesaian Sengketa tanah Di Indonesia melalui Revitalisasi Fungsi Badan Peradilan, Jurnal Hukum, 2007, Vol.14, h. 464

10 Rasmadi Murad. 1991. Penyelesaian Sengketa Hukum Atas Tanah. Bandung: Penerbit Alumni, h. 22 
KERTHA PATRIKA

Volume 38, Nomor 1, Januari-April 2016

\subsection{Rumusan Masalah}

Berdasarkan latar belakang masalah tersebut, maka penulis tertarik untuk membedah permasalahan :

1. Bagaimanakah bentuk mediasi yang cocok untuk penyelesaian sengketa tanah sehingga dapat lebih efektif untuk menyelesaikan sengketa tanah..?

\section{PEMBAHASAN}

Mediasi saat ini merupakan cara menyelesaikan sengketa yang sedang digalakkan, hal ini sesuai dengan arah kebijakan dan strategi pembangunan hukum yang termuat dalam Peraturan Presiden Nomor 2 Tahun 2015 tentang Rencana Pembangunan Jangka Menengah Nasional melalui pelaksanaan Reformasi Sistem Hukum Perdata yang mudah dan cepat khususnya penegakan hukum perdata. Penyelesaian perkara perdata dilakukan dengan mendorong optimalisasi proses mediasi di pengadilan dan penyederhanaan prosedur perkara perdata diharapkan dapat mendorong efiesiensi penyelesaian perkara perdata.

Perkembangan di Amerika Serikat dewasa ini juga sangat mendorong ke arah pemanfaatan dan pemberdayaan Alternative Dispute Resolution (ADR), khususnya mediasi dengan tujuan mempercepat penyelesaian, serta memelihara fairness dan efisiensi ${ }^{11}$, Hal senada juga dilakukan di Jepeng, nediasi sangat relevan iterapkin dalan kasus-kasus sum Chot $i^{12}$ di Jepang bertujuan untuk menghindarkan litigasi dan menyelesaikan sengketa melalui mediasi. Tingkat keberhasilan chotei di Jepang mencapai 75\% - 85\%. Perkara yang spesipik dan belum diajukan ke pengadilan di selesaikan melalui chotei $^{13}$.

Mediasi di luar pengadilan adalah mekanisme penyelesaian sengketa sebelum perkaranya dibawa ke pengadilan. Cara ini dapat di tempuh para pihak dan dapat menjadi alternatif menyelesaikan sengketa tanpa melibatkan pihak pengadilan. Berdasarkan Undang-Undang Nomor 30 Tahun 1999 tentang Arbitrase dan Alternatif Penyelesaian Sengketa Pasal 6 ayat (1) dan ayat (2) menyatakan bahwa sengketa atau beda pendapat perdata dapat diselesaikan oleh para pihak melalui altenatif penyelesaian sengketa yang didasarkan pada itikad baik dengan mengesampingkan penyelesaian secara litigasi di pengadilan. Penyelesaian sengketa atau beda pendapat dimaksud diselesaikan dalam pertemuan langsung oleh para pihak.

Berdasarkan Undang-Undang Nomor 30 Tahun 1999 mediasi merupakan kelanjutan negosiasi (pertemuan langsung) dan dilaksanakan jika proses negosiasi telah gagal. Sebagaimana

11 Lisa A. Lomax. 2003. Proceedings: Rangkaian Lokakarya Terbatas Hukum Kepailitan dan Wawasan Hukum Bisnis Lainnya: tentang PenyempurnaanUndang-Undang Kepailitan. Jakarta: Penerbit PPH, h. 36

12 Chotei adalah mediasi. Di Jepang, mekanisme Chotei disamping diawali dengan adanya gugatan yang selanjutnya dilimpahkan ke chotei, diperbolehkan pula chotei langsung tanpa didahului oleh gugatan terlebih dahulu. Chotei dilakukan di di Pengadilan Sumir. Lihat Yoshiro Kusano. 2015. "Peran Sistem Wakai (Perdamaian) dan Chotei (Mediasi) Di Jepang", makalah pada Seminar Internasional kerjasama Japan Indonesia Lawyers Association dan Universitas Lambung Mangkurat, Banjarmasin. h. 8-9.

13 Kelompok Kerja Mediasi MA RI 2009. 2009. Laporan Studi Banding Improvement on Court Annexed Mediation Mahkamah Agung RI-JICA 31 Oktober-14 Nopember 2009. Jakarta: Tanpa penerbit, h. 6 
diatur dalam Pasal 6 (2) UU Nomor 30 Tahun 1999 yang menyebutkan "Penyelesaian sengketa atau beda pendapat melalui alternatif penyelesaian sengketa diselesaikan dalam pertemuan langsung (negosiasi_penulis) oleh para pihak dalam waktu paling lama 14 (empat belas) hari dan hasilnya dituangkan dalam suatu kesepakatan tertulis" Selanjutnya dalam ayat (3) secara jelas disebutkan, "Dalam hal sengketa atau beda pendapat sebagaimana dimaksud dalam ayat (2) tidak dapat diselesaikan, maka atas kesepakatan tertulis para pihak, sengketa atau beda pendapat diselesaikan melalui bantuan seorang atau lebih penasihat ahli maupun seorang mediator".

Mediasi yang diatur secara khusus dalam Peraturan Menteri Agraria Dan Tata Ruang/ Kepala Badan Pertanahan Nasional Republik Indonesia Nomor 11 Tahun 2016 tentang Penyelesaian Kasus Pertanahan, dapat dilakukan apabila para pihak bersedia menyelesaikan sengketa tanah yang bukan merupakan kewenangan kementerian ${ }^{14}$. Penyelesaian sengketa tanah selain kewenangan kementerian dapat dilakukan melalui mediasi. Apabila setelah dilakukan pendataan ditemukan bahwa sengketa tanah yang terjadi bukan merupakan kewenangan kementerian sebagaimana dinyatakan dalam Pasal 11 ayat (3), maka pejabat yang bertanggungjawab dalam menangani sengketa menyampaikan penjelasan tertulis kepada pihak pengadu yang berisi memuat pernyataan bahwa penyelesaian sengketa tanah diserahkan kepada pihak pengadu.

Apabila para pihak bersedia untuk melakukan mediasi, maka mediasi dilaksanakan berdasarkan prinsip musyawarah untuk mufakat bagi kebaikan semua pihak. Mediasi dilaksanakan paling lama 30 (tiga puluh) hari. Tujuan mediasi dalam sengketa tanah adalah :

1. Menjamin transparansi dan ketajaman analisis

2. Pergambilan put isan trang bersifat kolektif dan bbjektif

3. Nrerhinimalisisr gugatan atas liasil peiryelesàian sengketa

4. Menampung informasi/pendapat dari semua pihak yang berselisih, dari undur lain yang perlu dipertimbangkan

5. Memfasilitasi penyelesaian sengketa melalui musyawarah ${ }^{15}$

Pengaturan mediasi sengketa tanah di kantor pertanahan sebagaimana Pasal 39 ayat (1) Peraturan Menteri Agraria Dan Tata Ruang/Kepala Badan Pertanahan Nasional Republik Indonesia Nomor 11 Tahun 2016 tentang Penyelesaian Kasus Pertanahan bahwa peserta mediasi ditentukan sebagai berikut :

a. Tim Pengolah

${ }^{14}$ Sengketa tanah yang menjadi kewenangan Kementerian menurut ketentuan Pasal 11 ayat (3) adalah :

a. Kesalahan prosedur dalam proses pengukuran, pemetaan dan/atau perhitungan luas

b. Kesalahan prosedur dalam proses pendaftaran penegasan dan/atau pengakuan hak atas tanah bekas milik adat

c. Kesalahan prosedur dalam proses penetapan dan/atau pendaftaran hak tanah

d. Kesalahan prosedur dalam proses penetapan tanah terlantar

e. Tumpang tindih hak atau sertifikat hak atas tanah yang salah satu alas haknya jelas terdapat kesalahan

f. Kesalahan prosedur dalam proses pemeliharaan data pendaftaran tanah

g. Kesalahan prosedur dalam proses pemeliharaan data pendaftaran tanah

h. Kesalahan dalam memberikan informasi data pertanahan

i. Kesalahan prosedur dalam proses pemberian izin

j. Penyalahgunaan pemanfaatan ruang, atau

k. Kesalahan lain dalam penetapan peraturan perundang-undangan

15 Pasal 38 ayat (3) Peraturan Menteri Agraria Dan Tata Ruang/Kepala Badan Pertanahan Nasional Republik Indonesia Nomor 11 Tahun 2016 tentang Penyelesaian Kasus Pertanahan (Berita Negara Rapublik Indonesia Nomor 569 Tahun 2016) 
b. Pejabat Kementerian, Kantor Wilayah BPN dan/atau Kantor Pertanahan

c. Mediator dari Kementerian, Kantor Wilayah BPN dan/atau Kantor Pertanahan

d. Para pihak dan/atau pihak lain yang terkait dan/atau

e. Pakar dan/atau ahli yang terkait dengan sengketa, instansi terkait dan unsur masyarakat, tokoh masyarakat/adat/agama atau pemerhati/pegiat agrarian dan penataan ruang, serta unsur-unsur lain apabila diperlukan.

Selain para pihak, maka peserta mediasi sebagaimana ketentuan Pasal 39 ayat (1) tersebut harus mendapatkan penugasan dari Kementerian. Apabila mediasi tidak dihadiri oleh para pihak padahal sudah diundang secara patut selama 3 kali berturut-turut maka mediasi dinyatakan batal, dan para pihak dipersilahkan menyelesaikan sengketa tanah sesuai ketentuan peraturan perundang-undangan. Dalam hal salah satu pihak menolak melakukan mediasi atau mediasi batal karena sudah 3 kali tidak memenuhi undangan atau telah melampaui waktu 30 hari, Kepala Kantor Pertanahan membuat surat pemberitahuan kepada pihak pengadu bahwa pengaduan atau mediasi telah selesai disertai dengan penjelasan.

Pelaksanaan mediasi dicatat dalam notulensi dan hasil pelaksanaan mediasi dituangkan dalam Berita Acara Mediasi, yang memuat :

a. Pokok masalah

b. Kronologi

c. Uraian masalah, dan

d. Hasil necuiasi

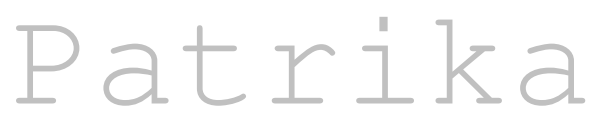

Notulen mediasi ditandatangani oleh mediator dan notulis, sedangkan Berita acara ini ditandatangani oleh Pejabat Kementerian, Kantor Wilayah BPN dan/atau Kantor Pertanahan, Mediator dan para pihak serta perwakilan peserta. Dalam hal salah satu pihak tidak mau menandatangani berita acara mediasi, maka ketidaksediaan tersebut dicatat dalam Berita Acara Mediasi. Dalam hal mediasi menemukan kesepakatan, maka akan dibuat Perjanjian Perdamaian berdasarkan berita acara mediasi yang mengikat para pihak. Perjanjian perdamaian didaftarkan pada Kepaniteraan Pengadilan Negeri setempat sehingga mempunyai kekuatan hukum mengikat.

Berdasarkan ketentuan pelaksanaan mediasi baik yang diatur dalam Undang-undang Nomor 30 Tahun 1999 maupun yang diatur dalam Peraturan Menteri Agraria Dan Tata Ruang/ Kepala Badan Pertanahan Nasional Republik Indonesia Nomor 11 Tahun 2016 tentang Penyelesaian Kasus Pertanahan maka ditemukan bahwa dalam kedua ketentuan tersebut tampak kaitan erat antara mediasi dan negosiasi. Mediasi merupakan suatu proses dimana mediator yang telah disepakati oleh pihak-pihak yang bersengketa, bertindak sebagai fasilitator bagi kepentingan negosiasi, yang membantu para pihak tersebut mencapai solusi yang saling menguntungkan. Jadi dapat disimpulkan bahwa proses negosiasi antara para pihak untuk menemukan kesepakatan dengan cara musyawarah mufakat menjadi inti dalam penyelesaian sengketa melalui mediasi.

Pada prinsipnya mediasi adalah berisi negosiasi yang melibatkan pihak penengah yang netral dan tidak memihak serta dapat membantu para pihak untuk melakukan tawar menawar secara seimbang. Tanpa negosiasi tidak ada mediasi, mediasi merupakan bentuk perluasan dari sebuah negosiasi sebagai mekanisme alternatif penyelesaian sengketa dengan bantuan seorang mediator. 
Dengan demikian, inti dari sebuah mediasi merupakan negosiasi yaitu bentuk penyelesaian sengketa dengan cara pertemuan langsung kedua belah pihak yang bersengketa untuk menemukan penyelesaian dibantu oleh pihak ketiga netral. Posisi mediator dalam proses mediasi hanyalah sebagai fasilitator yang membantu berupa memberikan fasilitas kepada kedua belah pihak untuk bernegosiasi menemukan kesepakatan. Sehingga mediasi yang efektif apabila dilakukan oleh para pihak yang bernegosiasi dilandasi dengan itikad baik untuk menyelesaikan masalah.

Menurut Christoper W. Moore, karakteristik sengketa yang efektif dapat diselesaikan melalui mediasi adalah sebagai berikut ${ }^{16}$ :

1. Para pihak yang bersengketa memiliki sejarah pernah bekerja sama dan berhasil dalam menyelesaikan masalah mengenai beberapa hal

2. Para pihak tidak memiliki sejarah panjang saling menggugat di pengadilan sebelum melakukan proses mediasi

3. Jumlah pihak yang terlibat dalam sengketa tidak meluas sampai pada pihak-pihak yang berada di luar masalah

4. Pihak-pihak yang terlibat dalam sengketa telah sepakat membatasi permasalahan yang akan di bahas

5. Para pihak mempunyai keinginan besar untuk menyelesaikan masalah mereka

6. Para pihak telah mempunyai atau akan mempunyai hubungan lebih lanjut di masa yang akan datang

7. Tingkat kemarahan dari para pihak masih dalam batas normal

8. Tara pihak oersedia menerima bant iar pönck îetiga

9. Terdapat alasan-alasan kuat untuk menyelesaikan sengketa

10. Para pihak tidak memiliki persoalan psikologis yang benar-benar dapat mengganggu hubungan para pihak

11. Terdapat sumberdaya untuk tercapainya sebuah kompromi

12. Para pihak mempunyai kemauan untuk saling menghargai

Salah satu tugas penting mediator adalah untuk mengalihkan perundingan dari positional claim menjadi underlying interest. Menurut Eric Brahm and Julian Quellet, ${ }^{17}$ bahwa model ideal dalam penyelesaian sengketa yang efektif adalah dengan mengedepankan bentuk negosiasi yang menitikberatkan pada aspek kepentingan-kepentingan yang berkaitan dengan persoalan yang diajukan oleh para pihak. Intinya mediasi memberikan penekanan pada kemanfaatan bagi para pihak dalam menyelesaikan sengketa yang dihadapi.

Menurut William Ury, Jeanne Brett dan Stephen Goldberg ${ }^{18}$, negosiasi dalam mediasi yang dapat menjadi cara yang efektif untuk menyelesaikan sengketa melalui :

1. Negotiating interests is less expensive than adjudicating rights or purcusing power options

\footnotetext{
16 Moore, Christoper. 1994. W, Disputes System Design, Pasipica Review 6 (2). h. 43-55

17 Brahm, Eric and Julian Quellet. 2003. Designing New Disputes Resolutions System, The Beyond Intractability Project: The Conflict Information Consortium University of Colorado. h. 36

18 William Ury, Jeanne Breet and Stephen Goldbreg. 1988. Getting Disputes Resolved: Designing System to Cut the Costs of Conflict. London: Jossey-Bass Publishers. h. 19
} 
2. Negotiating interests result in mutually satispactory solution, while the other two approaches are win-lose, meaning one side wins and the other side loses

3. When power-based approaches are tired, the losing side often is angry, and may try to get back at the other sidewhenever they get the chance

4. Interest based negotiation is usually less time consuming than the approaches

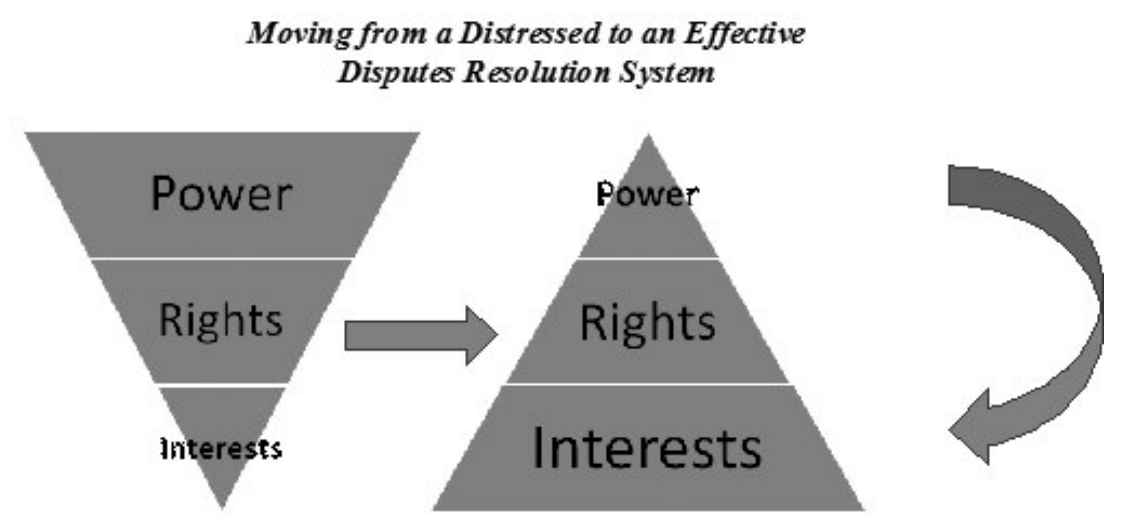

Distressed SystemEffective System

Melalui penekanan pada aspek interest maka berbagai kepentingan para pihak yang saling bersengketa dapat diakomodasikan dengan maksimal. Hal ini akan berpengaruh pada tingkat kepuasan para outhak dalain up iya pencapaian win-win solutions yang dipatus secara sukarela oleh kedua belah pihak.

Pemberdayaan mediasi dengan penekanan pada interest based dalam menyelesaikan sengketa tanah merupakan suatu hal yang dapat membawa dampak menguntungkan bagi kedua belah pihak. Mekanisme penyelesaian sengketa tanah melalui mediasi di luar pengadilan merupakan bentuk penyelesaian sengketa dengan mengurangi campur tangan negara (peradilan negara), penyelesaian sengketa ini lebih mengutamakan cara-cara kooperatif para pihak mengedepankan penyelesaian sengketa tanah dengan prinsip win-win solution.

Mediasi interest based merupakan perundingan para pihak yang difasilitasi mediator yang berdasarkan kepentingan, yaitu perundingan yang dimulai dengan mengembangkan dan menjaga hubungan. Para pihak berusaha memahami satu sama lain akan kebutuhan mereka dan bersama-sama menyelesaikan pesoalan berdasarkan pada kebutuhan-kebutuhan/kepentingan.

Ciri utama interest based dapat dilihat dari sikap/perilaku negosiator, yaitu :

a. Jika masalah diumpamakan sebagai sebuah kue, maka masing-masing negosiator beranggapan bahwa masalah tersebut adalah masalah bersama

b. Masing-masing negosiator mempunyai tujuan yang sama yaitu memecahkan masalah bersama

c. Kebutuhan dari seluruh pihak harus dibahas dalam rangka mencapai tujuan bersama

d. Para negosiator adalah "penyelesai masalah" yang kooperatif

e. Negosiator berusaha menjaga/membangun pola hubungan positif dan kepercayaan selama perundingan

f. Solusi yang ditawarkan tidak hanya satu tetapi terdapat beberapa pilihan penyelesaian yang memuaskan. 

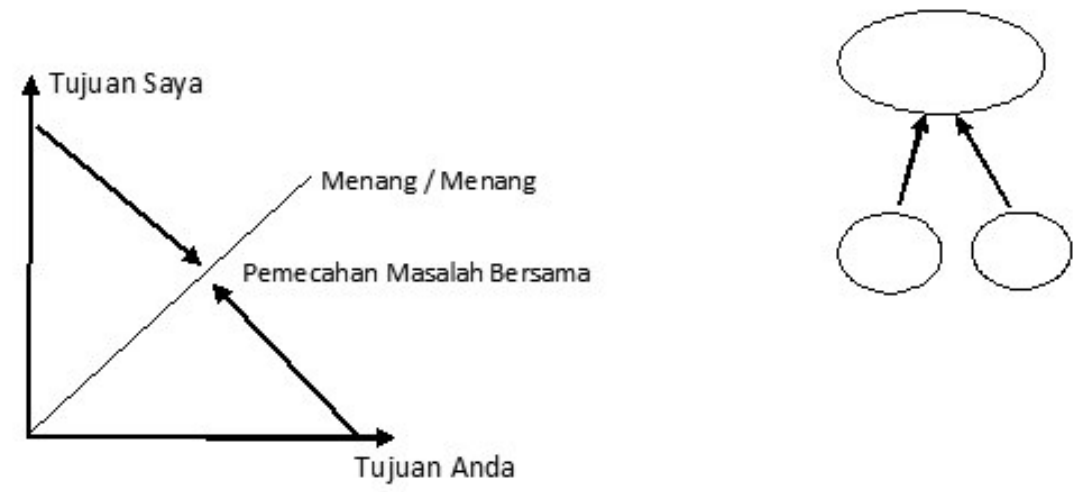

Proses perundingan melalui mediasi dikatakan ideal apabila memenuhi tiga kepuasan yaitu secara substansi, prosedural dan psikologis. Kepuasan secara subtansi merupakan kepuasan khusus dari para pihak yang bersengketa, misalnya dapat dipenuhinya ganti kerugian berupa uang, Kepuasan prosedural terjadi apabila para pihak mendapat kesempatan yang sama dalam menyampaikan gagasannya selama berlangsungnya perundingan atau karena adanya kesepakatan yang diwujudkan, sedangkan kepuasan psikologis adalah menyangkut tingkat emosi para pihak yang terkendali, saling menghargai, penuh keterbukaan serta dilakukan dengan sikap positif dalam memelihara hubungan pada masa-masa mendatang. ${ }^{19}$

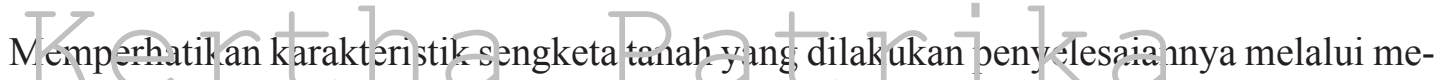
diasi, maka mediasi berbasis kepentingan cocok dalam penyelesaian sengketa tanah. Mediasi diarahkan substansi kepentingan para pihak, berdasarkan pada aspek penyelesaian bersama suatu permasalahan yang bertitik tolak unsur kepentingan bagi kedua belah pihak, menyelesaikan akar persoalan, menghindari konflik berkepanjangan antara para pihak, serta adanya keinginan untuk mempunyai hubungan baik jangka panjang.

\section{PENUTUP}

\subsection{Kesimpulan}

Sengketa tanah yang dapat diselesaikan melalui mediasi di luar pengadilan adalah sengketa tanah dalam ruang lingkup perdata yang berada di luar kewenangan kementerian. Model mediasi dalam penyelesaian sengketa tanah adalah mediasi berbasis kepentingan interest based, yaitu fokus mediasi diarahkan pada hak (rights) dan substansi kepentingan (interest) yang dilakukan oleh para pihak berdasarkan pada aspek penyelesaian bersama suatu permasalahan yang bertitik tolak pada unsur kepentingan terbaik bagi kedua belah pihak, dengan cara menyelesaikan akar persoalan, menghindari konflik berkepanjangan antara para pihak, serta adanya keinginan untuk mempunyai hubungan baik jangka panjang.

19 Wien Sakti Myharto, Penyelesaian Sengketa Tanah, www.hukumpedia.com, diakses tanggal 23 September 2016 


\section{DAFTAR PUSTAKA}

\section{A. Buku}

Brahm, Eric and Julian Quellet. 2003. Designing New Disputes Resolutions System, The Beyond Intractability Project: The Conflict Information Consortium University of Colorado.

Gunawan Widjaja dan Ahmad Yani. 2000. Hukum Arbitrase, Jakarta: Penerbit Raja Grafindo Persada.

Lisa A. Lomax. 2003..Proceedings: Rangkaian Lokakarya Terbatas Hukum Kepailitan dan Wawasan Hukum Bisnis Lainnya : tentang PenyempurnaanUndang-Undang Kepailitan, Jakarta: Penerbit PPH.

Kelompok Kerja Mediasi MA RI 2009.2009. Laporan Studi Banding Improvement on Court Annexed Mediation Mahkamah Agung RI-JICA 31 Oktober-14 Nopember 2009.

Moore, Christoper. W. 1994. Disputes System Design, Pasipica Review 6 (2).

Naskah Akademik MARI. Tahun 2005 Tentang Pembaharuan Sistem Peradilan.

Prosiding Mahkamah Agung RI. 2005. Mediasi dan Court Annexed Mediation. Jakarta: Penerbit Mahkamah Agung RI dan Pusat Pengkajian Hukum.

Rachmadi Usman. 2003. Pilihan Penyelesaian Sengketa Diluar Pengadilan, Bandung: Penerbit Citra Aditya Bakti.

Murad, Rasmadi.1991.Renteresuian Jengheia Hukum Etas Tanth. Bandung: Fenerbii Alumni.

William Ury, Jeanne Breet and Stephen Goldbreg. 1988. Getting Disputes Resolved: Designing System to Cut the Costs of Conflict, London: Jossey-Bass Publishers.

\section{B. Jurnal/Makalah}

Mudjiono, Alternatif Penyelesaian Sengketa tanah Di Indonesia melalui Revitalisasi Fungsi Badan Peradilan, Jurnal Hukum, 2007, Vol.14.

\section{Internet}

Yoshiro Kusano. 2015. “Peran Sistem Wakai (Perdamaian) dan Chotei (Mediasi) Di Jepang”, Makalah pada Seminar Internasional kerjasama Japan Indonesia Lawyers Association dan Universitas Lambung Mangkurat, Banjarmasin.

\section{Peraturan Perundang-undangan}

Peraturan Menteri Agraria Dan Tata Ruang/Kepala Badan Pertanahan Nasional Republik Indonesia Nomor 11 Tahun 2016 tentang Penyelesaian Kasus Pertanahan (Berita Negara Rapublik Indonesia Nomor 569 Tahun 2016

\section{E. Internet}

http://www.bpn.go.id/Program/Penanganan-Kasus-Pertanahan. diakses tanggal 29 oktober 2016.

www.hukumpedia.com. diakses tanggal 23 September 2016. 